\title{
Explaining Tourism Inflows in Greece: A Macroeconometric Approach
}

\author{
George M. Agiomirgianakis ${ }^{1} \&$ George Sfakianakis ${ }^{2}$ \\ ${ }^{1}$ Hellenic Open University, Greece \\ ${ }^{2}$ Central Greece University of Applied Sciences and Hellenic Open University, Greece \\ Correspondence: George M. Agiomirgianakis, 18 Parodos Aristotelous Str., Patras, 26335, Greece. E-mail: \\ gmagios@otenet.gr
}

Received: February 1, 2016

Accepted: February 23, 2016

Online Published: March 25, 2016

doi:10.5539/ijef.v8n4p192

URL: http://dx.doi.org/10.5539/ijef.v8n4p192

\begin{abstract}
This paper investigates the determinants of tourism inflows to Greece. The significance of the specific sector for the Greek economy varies from 15\% to $20 \%$ of GDP (measured directly or indirectly respectively). Building on the existing literature, panel data estimation techniques are used, with explanatory variables including selected macroeconomic indicators and (relative) price indices. The main innovation of the paper is that, regarding the cross section dimension of the sample, disaggregated data based on the country (or area) of origin are used, combined with the corresponding macroeconomic aggregates. The time-span of the data is the 2004-2010 period, with the specific econometric techniques used taking into account both the statistical properties of variables and the differences between the various cross sections. The main conclusion of the paper is that the macroeconometric approach to explaining tourist arrivals provides a very satisfactory model fit, with explanatory variables explaining a significant part of the variability of the dependent variable.
\end{abstract}

Keywords: tourism demand, panel data, macroeconometric approach

\section{Introduction}

This paper aims at investigating the determinants of tourism inflows to Greece in order to use it, among others, for forecasting purposes; given the significance of the specific sector for the Greek economy (accounting at least for $15 \%$ of total economic activity, both directly and indirectly), improved forecasting models and techniques would render overall macroeconomic forecasting more efficient. This is even more important at a time when a bottom-up approach in forecasting (from the sectoral to the national level) is debated and, in fact, recommended by many international organizations. Building on the existing literature, panel data estimation techniques are used, with explanatory variables including selected macroeconomic indicators and (relative) price indices. The main innovation of the paper is that, regarding the cross section dimension of the sample, disaggregated data based on the country (or area) of origin are used, combined with the corresponding macroeconomic aggregates. The time-span of the data is the 2004-2010 period, with the specific econometric techniques used taking into account both the statistical properties of variables and the differences between the various cross sections. The main conclusion of the paper is that the macroeconomic approach to explaining tourist arrivals provides a very satisfactory model fit, with explanatory variables explaining a significant part of the variability of the dependent variable; thus, a concrete basis for more reliable forecasting in the medium term is secured, with estimation outcomes being robust to the choice of econometric methods.

The structure of the paper is as follows: section 2 provides an overview of the relevant literature, also justifying the choice of the specific model and data structure described in section 3. In section 4, data sources and definitions are provided, to be followed by the empirical estimates of the model (section 5). The statistical properties of the variables are discussed in section 6 , while section 7 concludes.

\section{Links to the Existing Literature}

The literature examining tourism issues is rather extensive, with this fact being mainly explained by the characteristics of the specific sector. More specifically, as Stabler et al. (2010) have highlighted, the tourism "product" consists of distinct goods and services, bought at the same time or in sequence but, in any case, with the demand for one definitely affecting the demand for the other. The problem becomes more complex, as these 
goods and services are affected by a variety of different factors, thus rendering the aggregation process of determining factors a very demanding task. Most of the papers on the subject, however, fall into one of the broad categories Wanhill (2007) has indentified: the structure of the sector, macroeconomic impact assessment, demand modeling, tourism governance, supply issues, data analysis, statistical analysis. Papers on any of these issues are very scarce until the 1970s, while the literature has been growing at a fast pace since then. Useful surveys include Sheldon (1990), Eadington and Redman (1991), Wahab and Cooper (2001), Lew and Hall (2004), Hall and Page (2006).

Regarding the modeling of tourism demand, starting from the 1960s, an extensive literature exists, with useful surveys including Crouch (1994, reviewing more than 300 publications), and Lim (1997a, 1997b, 1999). The strand of literature basing demand modeling on panel data is somewhat more recent, starting from Naude and Saayman (1985), Van der Merwe at al. (2007), Saayman and Saayman (2008). We opted for this type of analysis, following the conclusions of Stabler et al. (2010) that, in this case, as the quantity and quality of data are enhanced, data are more informative, the degrees of freedom increase and estimates tend to be more efficient while suffering less from multicollinearity.

\section{Description of the Model}

Based on the above mentioned literature review, we have opted for a single equation approach to be estimated with panel data. Our basic equation includes the main variables recent research suggests (see, for example, Stabler et al., Dwyer et al., 2010):

$\Rightarrow$ The income in the country of origin: the purchasing power of people in one country positively affects their ability and inclination for both internal and international tourism.

$\Rightarrow$ The cost of living at the destination relative to the origin: given the fact that tourists incur specific costs at the place of their destination, it is natural to assume that they compare prices between the destination and their home country; as a result, their decision on whether or not to visit a destination depends on the relative costs of living (see, among others, Dwyer et al., 2010).

$\Rightarrow$ The cost of living at other (competitive) destinations: given that a significant degree of substitutability between alternative destinations exists (although country-specific characteristics may limit it), a rise in price in one destination is expected to boost the number of visitors to substitute destinations; in fact, we assume that tourists are in a process of considering a range of competing destinations before making their final choice.

$\Rightarrow$ Transportation costs: this is actually part of the overall cost of traveling to a destination, so it is straightforward to assume that it affects travelers' decisions. The difficulty of deciding on the right proxy for transportation costs has led many researchers to omit this variable altogether. This difficulty pertains, among others, to the fact that often alternative ways of traveling exist (surface travel, air travel, sea transport) and, even more, for each one of these a variety of classes/fares is available (the pricing practices of airlines resulting to a multitude of fares is a good example in this respect).

\section{Data Sources and Definitions}

In this section, a brief description of data sources and definitions is provided. The dependent variable is represented by the revenue from tourist arrivals from specific countries/areas. The source is the Bank of Greece and relevant data are deflated for all countries using the CPI obtained by EL.STAT. The sample of countries includes Austria, Belgium, France, Germany, Spain, Italy, Cyprus, Netherlands, Denmark, UK, Romania, Sweden, Czech Republic, Albania, Australia, Switzerland, USA, Canada, Russia, EE-27 and the euroarea (Note 1). The time frame is the period from 2004 to 2010 , as at the time the paper was written, only provisional data were available for subsequent years (thus rendering comparisons with previous years questionable).

The proxy we chose for the purchasing power of other country residents is GDP per capita at constant prices and purchasing power parities (source: OECD). For non-OECD members, we used the same variable from Penn World Tables (ver. 7.3, 2011).

Following the standard practice in the literature, we used effective exchange rates (relative to the effective exchange rate of Greece) in order to grasp the effect of relative prices. Again, the source for this variable is OECD, while the AMECO database was also used for the EU-27 and the euroarea aggregates. The same variable was used in order to construct a (non-weighted) average of relative prices for competitive countries. The countries chosen for this purpose were Turkey, Cyprus, Spain, Portugal and Malta.

Given the fact that Greece is accessible by almost all alternative ways of traveling (at least from many European 
countries of origin), we opted for a more general proxy for the transportation cost, i.e., the international price of oil which would be expected to affect the cost of all of them (although admittedly not necessarily in a uniform way). The fact that we use panel data to a certain degree justifies this choice, as factors (such as distance from the country of origin) is a constant in each of the cross sections for all years; as a result, the cost of traveling to Greece is actually affected by factors changing over time (most notably, oil prices).

\section{Empirical Results}

In this section we present our empirical estimates for the determinants of tourism inflows in Greece. The model specifications eventually chosen with statistical / econometric criteria are presented in Tables 1 and 2 . We should note that, before concluding, various alternatives were tried, as per: (i) the combination of variables, (ii) data sources, (iii) econometric methods.

Regarding the latter, eventually the equation was estimated using Panel EGLS, with country weights and diagonal correction of standard errors for heteroscedasticity and autocorrelation (using the methodology of White). Specifications with both fixed and random effects were tried, but their performance was relatively inferior based on the usual statistical/econometric criteria. Also, apart from allowing for a different residual variance for each cross section (captured by the country weights), there is no indication that the data structure is characterized by period specific heteroskedasticity, contemporaneous covariances, and between-period covariances (given, in any case, the relatively small time dimension).

Table 1. Determinants of tourism inflows in Greece (variables in levels)

Dependent Variable: Tourism receipts

Method: Panel EGLS (Cross-section weights)

Periods included: 7

Cross-sections included: 20

Total panel (unbalanced) observations: 137

White cross-section standard errors \& covariance (d.f. corrected)

\begin{tabular}{|c|c|c|c|c|}
\hline Variable & Coefficient & Std. Error & t-Statistic & Prob. \\
\hline Constant & -14.78856 & 6.088564 & -2.428907 & 0.0167 \\
\hline Real GDP & 0.000454 & 0.000136 & 3.344175 & 0.0011 \\
\hline Relative real effective exchange rate & 6.399098 & 2.476910 & 2.583501 & 0.0111 \\
\hline Competitors real effective exchange rate & 0.086200 & 0.021986 & 3.920773 & 0.0002 \\
\hline Oil price & -0.048712 & 0.007301 & -6.671871 & 0.0000 \\
\hline Dummy for 2004 & 0.482953 & 0.127918 & 3.775493 & 0.0003 \\
\hline Economic crisis dummy & -1.511684 & 0.153443 & -9.851796 & 0.0000 \\
\hline \multicolumn{5}{|c|}{ Weighted Statistics } \\
\hline R-squared & 0.970622 & Mean dependent var & & 13.41900 \\
\hline Adjusted R-squared & 0.964006 & S.D. dependent var & & 14.18667 \\
\hline S.E. of regression & 2.486746 & Sum squared resid & & 686.4134 \\
\hline F-statistic & 146.6957 & & & \\
\hline \multirow[t]{2}{*}{ Prob(F-statistic) } & 0.000000 & & & \\
\hline & Unweighte & d Statistics & & \\
\hline R-squared & 0.981876 & Mean dependent var & & 12.08750 \\
\hline Sum squared resid & 1151.486 & & & \\
\hline
\end{tabular}

Table 2. Determinants of tourism inflows in Greece (variables in logarithms)

Dependent Variable: Tourism receipts

Method: Panel EGLS (Cross-section weights)

Sample: 20042010

Periods included: 7

Cross-sections included: 20

Total panel (unbalanced) observations: 137

White cross-section standard errors \& covariance (d.f. corrected) 


\begin{tabular}{lcrrc}
\hline \multicolumn{1}{c}{ Variable } & Coefficient & Std. Error & t-Statistic & Prob. \\
\hline Constant & -12.92546 & 2.467249 & -5.238815 & 0.0000 \\
Real GDP & 0.161980 & 0.062758 & 2.581012 & 0.0112 \\
Relative real effective exchange rate & 0.783028 & 0.189664 & 4.128498 & 0.0001 \\
Competitors real effective exchange rate & 2.945350 & 0.431600 & 6.824250 & 0.0000 \\
$\quad$ Oil price & -0.284671 & 0.029633 & -9.606456 & 0.0000 \\
Dummy for 2004 & 0.176309 & 0.030959 & 5.694958 & 0.0000 \\
Economic crisis dummy & -0.212912 & 0.017024 & -12.50640 & 0.0000 \\
\hline R-squared & Weighted Statistics & & 2.181210 \\
Adjusted R-squared & 0.995224 & Mean dependent var & & 2.372074 \\
S.E. of regression & 0.994149 & S.D. dependent var & & 2.351563 \\
F-statistic & 0.145552 & Sum squared resid & & \\
Prob(F-statistic) & 925.2652 & & \\
\hline & 0.000000 & & \\
\hline R-squared & Unweighted Statistics \\
Sum squared resid & 0.987901 & Mean dependent var \\
\hline
\end{tabular}

The overall fitness of both models is very good, with independent variables explaining a significant part of the variance of the dependent variable (as shown by the corrected $R^{2}$ and the test on its statistical significance using the F-statistic). All estimators are statistically significant at the $1 \%$ statistical significance level and have the expected sign, i.e.:

(a) improving standards of living in other countries (as depicted by real GDP per head - PPP corrected) result to increasing tourism outflows from these countries and, thus, increasing tourism inflows in Greece (among other destinations),

(b) the increase in relative prices in other countries (with Greece as the denominator) favours the tourism inflows in Greece and the same holds for the increase of relative prices in competitor countries,

(c) the increase in the cost of traveling abroad negatively affects tourism flows in general and, more specifically, travel receipts in Greece,

(d) major events (such as hosting the Olympic Games, which is what happened within our sample period) positively affect tourism receipts,

(e) the recent economic crisis affected tourism inflows and receipts in an adverse way which goes beyond, for example, the simple income effect (captured by the change in GDP per head).

\section{Stationarity Concerns}

In this section, test results for stationarity are presented for the series used in the regressions of the previous section in order to ensure that the spurious correlation problem has been avoided. Should this be the case, estimators could be inconsistent, rendering t-statistics unreliable (Note 2).

These test results are depicted in Tables 3 and 4. More specifically, we present the results of the Levin, Lin, and Chu (2002) test (assuming one unit root for the panel series), along with the results of the Im, Pesaran and Shin (2003) and Maddala - Wu (1999) - Choi (2001) tests, based on which the ADF - Fisher Chi-square and PP Fisher Chi-square statistics. These last three statistics are based on the assumption that a distinct unit root exists for each unit of the panel. In most cases, test results coincide on the rejection of the hypothesis of a unit root at conventional levels of statistical significance. In those cases where test results are contradictory the results of the Fisher-type tests are adopted, following Maddala - Wu (1999).

The overall conclusion is that the empirical results of this section are valid and that there is no issue of a spurious relationship. 
Table 3. Results of Panel Unit root tests (variables in levels)

\begin{tabular}{lcccc}
\hline & Levin, Lin \& Chu t* & $\begin{array}{c}\text { Im, Pesaran and } \\
\text { Shin W-stat }\end{array}$ & $\begin{array}{c}\text { ADF - Fisher } \\
\text { Chi-square }\end{array}$ & $\begin{array}{c}\text { PP - Fisher } \\
\text { Chi-square }\end{array}$ \\
\hline Real GDP per capita & -5.53 & -0.44 & 35.99 & 56.79 \\
Marginal probability of rejection of Ho & 0.00 & 0.33 & 0.47 & 0.02 \\
Relative prices & -0.29 & 1.37 & 7.17 & 38.49 \\
Marginal probability of rejection of Ho & 0.39 & 0.92 & 0.93 & 0.04 \\
Index of competitors' prices & -1.22 & 0.41 & 13.75 & 49.13 \\
Marginal probability of rejection of Ho & 0.11 & 0.66 & 0.84 & 0.03 \\
International oil prices & -10.12 & 3.24 & 62.03 & 74.68 \\
Marginal probability of rejection of Ho & 0.00 & 0.00 & 0.00 & 0.00 \\
\hline
\end{tabular}

Table 4. Results of Panel Unit root tests (variables in logs)

\begin{tabular}{ccccc}
\hline & $\begin{array}{c}\text { Levin, Lin \& } \\
\text { Chu t* }\end{array}$ & $\begin{array}{c}\text { Im, Pesaran and } \\
\text { Shin W-stat }\end{array}$ & $\begin{array}{c}\text { ADF - Fisher } \\
\text { Chi-square }\end{array}$ & $\begin{array}{c}\text { PP - Fisher } \\
\text { Chi-square }\end{array}$ \\
\hline Real GDP per capita & -5.64 & -0.46 & 36.21 & 58.02 \\
Marginal probability of rejection of $\boldsymbol{H}_{\boldsymbol{o}}$ & 0.00 & 0.32 & 0.46 & 0.01 \\
Relative prices & -0.52 & 1.28 & 8.54 & 57.92 \\
Marginal probability of rejection of $\boldsymbol{H}_{\boldsymbol{o}}$ & 0.30 & 0.90 & 0.86 & 0.03 \\
Index of competitors' prices & -1.24 & -5.93 & 13.76 & 47.96 \\
Marginal probability of rejection of $\boldsymbol{H}_{\boldsymbol{o}}$ & 0.11 & 0.00 & 0.84 & 0.03 \\
International oil prices & -12.79 & -3.57 & 80.09 & 127.66 \\
Marginal probability of rejection of $\boldsymbol{H}_{\boldsymbol{o}}$ & 0.00 & 0.00 & 0.00 & 0.00 \\
\hline
\end{tabular}

\section{Conclusion}

In this paper we aimed at investigating the determinants of tourism inflows in Greece from a macroeconometric perspective. Using panel data for 20 countries/regions for a time span of 7 years, we evaluated the explanatory power of GDP per head (in PPP terms), relative prices, the prices in main competitive countries, the cost of traveling abroad (using the price of oil as a proxy) and extraordinary circumstances (such as major events hosted by the country or the economic crisis - both captured by dummy variables).

The fit of the model comprising these variables was very satisfactory and robust both to the specification (levels or logs) and the estimation methods; moreover, the statistical properties of the variables were properly tested and accounted for. Given the fact that forecasts for the main independent variables are readily available, this would facilitate the forecasting process for the specific sector of the Greek economy; this, in turn, would render macroeconomic forecasting more credible, at least if estimates for idiosyncratic factors for every period are possible.

Future lines of research include the expansion of the model to facilitate short-term forecasting, using lower frequency data (quarterly or even monthly data) and statistical techniques appropriate for explaining short-term developments. Also, should relevant data be credibly acquired, an additional variable could be included to capture the effect of marketing expenditure, in order to evaluate the actual contribution of usually costly but doubtfully effective campaigns.

\section{References}

Choi, I. (2001). Unit Root Tests for Panel Data. Journal of International Money and Finance, 20, 249-272. http://dx.doi.org/10.1016/S0261-5606(00)00048-6

Crouch, G. I. (1994). The Study of International Tourism Demand: A review of Practice. Journal of Travel Research, 33, 41-54. http://dx.doi.org/10.1177/004728759403200408

Dwyer, L., Forsyth, P., \& Dwyer, W. (2010). Tourism Economics and Policy. Channel View Publications, London.

Eadington, J. R., \& Redman, M. (1991). Economics and Tourism. Annals of Tourism Research, 18, 41-56. http://dx.doi.org/10.1016/0160-7383(91)90038-D

Hall, C. M., \& Page, C. J. (2006). The Geography of Tourism and Recreation: Environment, Place and Space. 
London: Routledge.

Im, K. S., Pesaran, M. H., \& Shin, Y. (2003). Testing for Unit Roots in Heterogeneous Panels. Journal of Econometrics, 115, 53-74. http://dx.doi.org/10.1016/S0304-4076(03)00092-7

Levin, A., Lin, C. F., \& Chu C. (2002). Unit Root Tests in Panel Data: Asymptotic and Finite-Sample Properties. Journal of Econometrics, 108, 1-24. http://dx.doi.org/10.1016/S0304-4076(01)00098-7

Lew, A. A., Hall, C. M., \& Williams, A. M. (2004). A companion to tourism. Oxford: Blackwell. http://dx.doi.org/10.1002/9780470752272

Lim, C. (1999). A meta-analysis review of international tourism demand. Journal of Travel Research, 37, 273-284. http://dx.doi.org/10.1177/004728759903700309

Lim, C. (2006). Tourism demand modeling: Issues and implications. In L. Dwyer, \& P. Forsyth (Eds.), International Handbook of Tourism Economics. Edward Elgar, London. http://dx.doi.org/10.4337/9781847201638.00008

Maddala, G. S., \& Wu, S. (1999). A Comparative Study of Unit Root Tests with Pane 1 Data and A New Simple Test. Oxford Bulletin of Economics and Statistics, 61, 631-652. http://dx.doi.org/10.1111/1468-0084.61.s1.13

Naude, W. A., \& Saayman, A. (1985). Determinants of tourist arrivals in Africa: A panel data regression analysis. Tourism Economics, 11, 365-391. http://dx.doi.org/10.5367/000000005774352962

Phillips, P., \& Moon, H. R. (1999). Linear Regression Limit Theory for Nonstationary Panel Data. Cowles Foundation for Research in Economics, Yale University. http://dx.doi.org/10.1111/1468-0262.00070

Saayman, A., \& Saayman, M. (2008). The determinants of Inbound Tourism to South Africa. Tourism Economics, 14(1), 81-96. http://dx.doi.org/10.5367/000000008783554893

Sheldon, P. J. (1990). A review of tourism expenditure research. In C. P. Cooper (Ed.), Progress in Tourism, Recreation and Hospitality Management (Vol. 2). London: Belhaven.

Stabler, M., Papatheodorou, A., \& Sinclair, T. M. (2010). The Economics of Tourism. New York: Routledge Publishers.

Van der Merwe, P., Saayman, M., \& Krugell, W. F. (2007). The determinants of the Spending of Biltong Hunters. South African Journal of Economics and Management Sciences, 10(2), 184-194.

Wahab, S., \& Cooper, C. (2001). Tourism in the Age of Globalization. London: Routledge.

\section{Notes}

Note 1. These are the countries for which the Bank of Greece provides data. We have only excluded some of the aggregates (e.g., EU-27 excluding the euroarea), for which the construction of relative prices and purchasing powers would be to a significant degree arbitrary.

Note 2. In any case, however, according to Phillips and Moon (1999) the problem of spurious correlation is less likely to occur when using panel data vs. time series data.

\section{Copyrights}

Copyright for this article is retained by the author(s), with first publication rights granted to the journal.

This is an open-access article distributed under the terms and conditions of the Creative Commons Attribution license (http://creativecommons.org/licenses/by/3.0/). 